\title{
Introduction: Contextualizing School Textbook Revision
}

\author{
Eckhardt Fuchs
}

$\mathrm{T}$

he words "textbook revision" immediately conjure up certain images. We generally think of conflicts surrounding the contents of textbooks, conflicts which are debated in public and usually have an international dimension. Textbook revision generally refers to books on history, geography and social studies, occasionally also religion or biology. It generally relates to those activities aimed at correcting false or distorted interpretations in school textbooks. In addition, it involves two further aspects: improving the quality of teaching with revised textbooks, and conveying universal norms in addition to knowledge of the subject. History and social studies teaching can thus make an important contribution to peace and human rights education.

The history and current practice of textbook revision suggest that we distinguish between two levels, the national and the international. First, there are a large number of textbook conflicts resulting from what are known as "history wars." These conflicts take place within a society at the national level, ${ }^{1}$ and are essentially differences of opinion about the development of national traditions, the maintenance of legitimation, and the construction of identity. History wars are not about facts but about the meaning of historical phenomena. Debates of this kind are typically not confined to their specialist field. They resonate broadly with the public and are often the subject of vehement debate.

An example of this can be found in the U.S.A., where the first controversies surrounding the introduction of national curricula and standards for history teaching broke out in 1994. These new standards constituted a break with the traditional master narrative of American national history, a break legitimized by academia and which addressed the demands of cultural emancipation movements. The reforms were immediately attacked by neo-conservative critics, who called for the new standards to "be flushed down the sewer of multiculturalism." 2

The past decade has seen increases around the world in this kind of public controversy about the interpretation of historical events, typically raising the question as to which of them should be included in history books. ${ }^{3}$ Generally speaking, we can say that these debates are prompted by an increasing dissociation of historical narratives from the history of the nation. On the one hand, we have the experience of a globalized world 
and the fact that the "unheard voices" of socially, religiously or ethnically disadvantaged groups are increasingly demanding that their history be acknowledged and taken into account. These factors are causing national narratives to be questioned and national history to be contextualized or even abandoned entirely. The challenges of multi-ethnic classrooms, as well as attempts to construct supranational identities (whether European or East Asian), highlight the limits of purely national narratives. And in many countries (particularly Western Europe, China, and Japan) the debate about a new perspective on national history, one anchored in world history, reflects a trend toward an expansion of the canon of national history to replace its traditional basic national narrative with a European or global perspective. ${ }^{4}$

In contrast to this trend, there is an undeniable neo-conservative trend that seeks to maintain traditional national history and dictate how identity is to be constructed in order to preserve specific national values. This is related to the attempt of national governments, and even the E.U., to have certain interpretations of history prescribed by law. ${ }^{5}$ One example of this is the law passed in February 2005 by the National Assembly in Paris requiring that French colonialism be portrayed positively in schoolbooks. ${ }^{6}$ We might also recall the ban imposed by the Turkish government on describing the Armenian genocide as such.

The second level, the level from which school textbook revision originates, is that of international relations - controversies pertaining not only to intrasocietal or national issues, but concerning two or more states. Two aspects are involved here. The first is the attempt to construct supranational identities - in Europe as well as in Asia. In Europe, this question is at the core of the current debate: Does the further progress of European integration depend on the emergence or even intentionally encouraged construction of a common European identity firmly embedded in a consensual concept of European history and memory? And if so, would a common European history textbook be the right medium in which to allow such an identity to evolve?

Up until now, within the European debate, one can observe a ritualized antagonism between two opposing camps. Those who would answer both questions positively point to current challenges posed by the strengthening of supranational institutions opting for a strategy aiming at the invention of a European identity, a strategy involving a common European history textbook. Skeptics respond with concern. They warn of the temptation to impose from above an artificially homogenized image of Europe, arguing that the sole common European history textbook that has been produced up until now confirms precisely these fears. Based on a notion of Europe which stresses Western Latin Christianity and the Enlightenment as essential elements of an allegedly unifying common inheritance, the textbook clearly falls into the hegemonic trap. Moreover, by 
defining Europe in these essentialist and Western-dominated terms, it implicitly excludes all those societies which do not share in that heritage. ${ }^{7}$

Such debates have not yet begun in Asia; however, attempts to create common history textbooks, such as between Japan, Korea and China, have led to similar problems. Can the political process of closer cooperation among Asian countries be promoted by a regional (Asian) identity consisting of a certain set of common traditions and values? And in what way can the European debate serve as a point of reference in both a positive as well as a negative manner?

The second aspect concerns the most fundamental objective of international textbook revision. This is to free textbooks of nationalistic and one-sided interpretations and, particularly in conflict and post-conflict societies, to promote reconciliation and peace. While the bilateral GermanFrench and German-Polish school textbook commissions are generally regarded as models of successful international textbook revision, the history of textbook revision in other regions is much less well known. And yet reforms in school teaching and textbooks have been discussed in the context of transnational education networks ${ }^{8}$ since the end of the nineteenth century ${ }^{9}$ and have been an integral part of the emerging system of multilateral education since the end of World War I. In the period between the two world wars, the textbook revision committees of the League of Nations formed a close network with a large number of newly established transnational organizations working in the field of education. These relationships played a large part in the emergence of an international discourse on history books and history teaching. While there was little direct influence on national education policies and scope for action remained limited to indirect governance on the basis of factors such as expert opinions, declarations, and documentation, the work of this early transnational civil society produced lasting effects.

This was particularly the case with school textbooks and teaching. The League of Nations responded to the initial suggestions for textbook revision with the 1925 adoption of the so-called "Casares Resolution." This resolution abandoned the original idea of internationally standardized teaching methods and materials but did provide for an international mechanism to supervise national curriculum revisions. ${ }^{10}$ However, the resolution had little effect, and in 1932 the League of Nations published a critical report on the state of school textbooks in the subjects history, geography, and civic and moral education. ${ }^{11}$ The International Conference on History Teaching in The Hague that year discussed the many different initiatives for the revision of history teaching that were being pursued independently by numerous transnational organizations. ${ }^{12}$ Although there was a consensus about the necessity to revise history textbooks, the participants disagreed about the way in which to do this. In the end the historians and history teachers calling for a revision based on the respective 
national curricula clearly prevailed over the largely pacifist parties advocating an internationally binding cultural history textbook.

The modest success achieved by the activities of the League of Nations as well as diverse other initiatives in the 1930s revealed the dilemma at the heart of school textbook revision: the League of Nations was unable to impose any binding conditions. However, all efforts without a certain legitimacy conferred by the League of Nations could only expect very limited success.

Despite the difficulties involved, an international declaration on history teaching was adopted by several countries in 1937. This document called for history instruction and textbooks to devote as much space as possible to the history of other nations and to prevent unjustified prejudices against other countries, and for national teachers' committees to be established in order to implement these guidelines. By 1939 the declaration had been signed by fifteen countries. ${ }^{13}$

Overall, however, the League of Nations proved to have only limited ability to coordinate the many and varied activities in the field of textbook revision. While there existed network-like relationships between the League of Nations and non-governmental organizations, there was seldom any direct coordination of content and objectives. Work was hampered by reservations from national and academic perspectives, and by competition between various interest groups - for instance between teachers and academics, or between elementary and secondary school teachers. The discrepancy between the Anglo-Saxon and the European initiatives also proved a hindrance. The Americans' goal of combining textbook revision and peace education with the political model of democracy ran contrary to the aims of European organizations, whose motivation for textbook revision was derived to a much greater extent from wartime experiences and had little to do with promoting such a political model.

For all these problems, the activities of the League of Nations formed the point of departure for numerous bilateral and regional agreements on school textbook revision, for instance between France and Germany in $1935^{14}$ and in Scandinavia. The revision movement spread to South America in the 1930s. In 1933 the seventh Pan-American Congress in Montevideo adopted a resolution on textbook revision, which was followed by a large number of bilateral agreements. ${ }^{15}$ And although the outbreak of war prevented the 1937 agreement from being implemented, the ideas it expressed were taken up again after $1945 .{ }^{16}$

Following World War II, efforts to revise school textbooks with direct international intervention were resumed on three levels: in the context of the re-education policy of the occupying powers in Germany and in Japan, at a bilateral level in particular between the formerly warring nations in Europe, and within the agenda of UNESCO and the Council of Europe. Not long after the war ended, the Allied Control Commission 
was already considering the revision of history books as a key tool for the ideological re-education of the young generation of Germans. With the outbreak of the Cold War, however, the establishment of new history curricula and textbooks soon led to conflicts between the American and Soviet representatives of the Allied Control Commission's education commission. ${ }^{17}$ Instead of the Marxist view of history favored by the Soviet occupation forces, the Western powers advocated the incorporation of history lessons into the subject of social studies, where knowledge of the democratic and liberal tradition of German history was considered part of a comprehensive democratic education. Textbook and curriculum issues were marginalized by the 1947/48 debates on a fundamental reform of school structure. Suggestions concerning the publication of a standardized history book for all four sectors of Berlin were not realized, and in late 1947 separate textbooks began to be published in the two occupied zones. The blockade of Berlin put an end to any common aspirations, and separate curricula with the appropriate textbooks were finally implemented with the creation of the two German states. While Soviet guidelines for history teaching and textbooks were adopted as far as possible in the GDR, plans for educational reform in the Western occupied zones were only partially realized.

History textbook revision in occupied Japan between 1945 and 1952 also pursued the objective of demilitarizing and democratizing Japanese primary and secondary school education. In particular, it was a matter of replacing the extremely nationalistic history books which had been produced until 1945 under the umbrella of the textbook division of the minister of education. The Civil Information and Education Section of the Supreme Commander for the Allied Powers worked closely together with Japanese authorities and academics on the revised textbooks, and in spring 1946, initial drafts were ready for submission. One year later, the new school system and curricula were established and textbook and curriculum matters decentralized. However, the shift in Allied occupation policy following 1948 in the context of the Cold War saw school reform efforts abandoned and a reintroduction of traditional structures. The new antimilitaristic and less nationalistic textbooks were heavily criticized by conservative groups. Their gradual replacement with textbooks leaning again towards nationalistic interpretations, especially in Japan, continues to arouse international criticism from China and Korea in particular. ${ }^{18}$

In West Germany, meanwhile, direct international influence tended to be exerted on a bilateral level. In the early 1950s, textbook content began to be coordinated between the Federal Republic of Germany and various other states. A number of British-German history conferences were held between 1949 and 1957, and from 1952 onwards German and French history teachers met regularly every two years. History books were the subject of intensive discussion at these meetings and were even mentioned 
explicitly in article 13 of the 1954 cultural agreement between France and Germany. ${ }^{19}$ The establishment of the Franco-German textbook commission proved an effective means of discussing and clearing up differences of opinion concerning interpretations of history, a development which resulted in 2006 in the publication of the first volume of a joint FrancoGerman history book. ${ }^{20}$ The commission consequently spawned many imitators, between Germany and other states as well as within and without Europe. These bilateral and multilateral textbook discussions are still considered the best example of mediating and solving textbook conflicts.

Along with facilitating these bilateral dialogues, UNESCO and the Council of Europe grew to be the international actors most directly involved in the promotion and acceleration of internationalization. At its very first session in 1946, UNESCO approved a nine-point program on the revision of textbooks and other teaching materials. Three years later, it produced a Handbook for the Improvement of Textbooks and Teaching Materials containing a standard contract for relevant international agreements. UNESCO held regular meetings and seminars on textbook work and on the content of history books - the focus here was on redressing a eurocentric view of history - and approved sample curricula. ${ }^{21}$ In 1957, UNESCO began publication of the History of the Cultural and Scientific Development of Mankind, comprising more than twenty volumes, for use by high school and college students around the world. In this way, then, the idea of an international history textbook was revived and the national orientation of textbooks replaced by a global approach. These initiatives continue today, although the main focus of UNESCO's textbook work is now the Arab world rather than Europe.

UNESCO's activities in the postwar period coincided with similar efforts by the Council of Europe. The process of European unification led to discussions on the continent about the representation of Europe and its history in school textbooks and lessons, and the Council of Europe held twelve conferences about history books and history teaching between 1953 and 1983. Effectively continuing the work of the League of Nations, they examined almost 1000 textbooks from seventeen countries. ${ }^{22}$ One key outcome of the conferences on revising these textbooks was the attempt to establish a terminology for historical concepts that could be used by all Europeans (Basic Terminology, 1964). At the meetings in Braunschweig in 1969 and in Strasbourg in 1971, it was recommended that both European and global history be included in the curriculum, with the objective that "the history of Europe should be viewed in a world perspective." ${ }^{23}$ However, both the Council of Europe and the European ministers of education rejected the idea of a standardized version of European history to be taught in schools. ${ }^{24}$

Some attempts were made in this direction all the same. One example was the first European History Book, written by twelve European historians 
and published in 1992 - an endeavor, however, which was met with general criticism. The idea of a standardized and binding history book of this kind was rejected at the 1997 conference of European ministers of education in Kristiansand, ${ }^{25}$ but the current debate indicates that the matter has again become one of public interest. However, the project, instigated primarily at a political level, is encountering skepticism from the academic community. The fragmented multitude of conceptions of Europe would appear to defy any single binding historical narrative, and there exist profound differences between the ways in which things are taught and learnt in the various European countries. Therefore it would be more useful to develop schoolchildren's awareness of the wealth of memories in Europe and the interpretative schemes of their neighbors than to construct a supranational, historical master narrative.

This brief historical outline covering the period since the 1920s makes it clear that international debates on textbook revision were a response to social and political phenomena: international understanding in the 1920s and following World War II in the context of UNESCO, awareness of Europe in the process of European unification, and finally, in recent years, global history as a response to globalization. For the geographical region of the European Union at least, it can be said that the decades-long work on textbook revision has resulted in nationalistic views of history largely disappearing from the history books and an increasing integration of European perspectives. This is the result (barring bilateral treaties) of agreements and recommendations by international committees. Consequently, effective revisions that go beyond declarations and translate into practice could only be realized by government and international authorities, whether the League of Nations or the European Union.

The essays collected in this volume explore textbook revision at both the national and the international levels. However, it will become apparent that there is considerable overlap between the various debates and that a strict division between national and international is impossible. The cause of the debate may serve as a criterion for distinguishing between intrasocietal agreement on the interpretation of historical events versus reconciliation with other nations.

The first three essays in this volume address controversies surrounding textbook revision on a national level. Georg Stöber and Basabi Khan Banerjee explore current changes in "traditional" textbook revision - that is, international revision aimed at reconciliation. They demonstrate that the existence of new civil wars and violent intrasocietal conflicts, the attempts to construct supranational identities, and the reality of multinational and multi-ethnic classrooms all pose new challenges for school textbook revision with regard to the increasing complexity of textbook revision and the diversity both of its objectives and of the people involved. This does not, in the authors' view, render international textbook revision 
obsolete. But the replacement of constricted identities with comprehensive identities calls for pragmatism, not idealism.

Deepa Nair provides a historical overview of school textbook revision at a national level, taking South Asia as an example, and focusing on India. Nair demonstrates how textbooks have played and continue to play a crucial role in the construction of national identity. This is particularly the case in the context of colonial and post-colonial experiences, where the dominant history narratives were constantly revised. The profound rupture caused by the division of the subcontinent along religious lines into separate countries had the additional effect of causing religious identities to supplant other forms of identity.

Exploring the Israeli-Arab conflict as represented in Israeli textbooks, Elie Podeh asks whether the new textbooks published since 2000 continue the decades-long trend towards a more balanced interpretation of the conflict. While one could have expected this trend to be revised in view of the intensification of the Middle East conflict since 2000, Podeh concludes that, despite recent tensions, there is no sign of negative stereotypes or racist images being perpetuated in the textbooks. He observes that the new textbooks do not differ significantly from those written at the time of the Oslo process.

The essay by Henri Elmersjö and Daniel Lindmark and that of Yangmo $\mathrm{Ku}$ address textbook revision on the international level from a historical perspective. Elmersjö and Lindmark outline the early days of international textbook revision, looking specifically at a supranational actor, the Norden Association. The association's objective was to evaluate textbooks in the Scandinavian countries and to submit recommendations for revision to the appropriate governments. The authors also place these activities in the context of a broad movement for peace education, which became a key aspect of the curriculum and of teaching following the end of World War I. However, support for revision came chiefly from history teachers at the secondary school level, while peace education was predominantly promoted at primary schools.

Yangmo Ku's analysis complements previous studies on the development and work of the German-Polish textbook commission by looking at how and why the context of textbooks underwent a shift with regard to the interpretation of the Polish neighbor. He embeds the development of the commission within the Ostpolitik of the Brandt era and demonstrates that the harsh conservative response to the suggestions of the commission was ultimately not strong enough to reverse the new interpretations, for instance with regard to the Oder-Neisse line or resettlement. He comes to the conclusion that effective textbook revision requires government support, but that the actual content of revisions should be left entirely to the specialists. 
School textbook revision and research are two sides of a coin. The latter is the very condition (at the most basic level, by analyzing textbook content) for textbooks to be able to be revised at all. This means that textbook research is caught between the competing interests of scholarship, politics, and teaching practice in terms of its practical application in the classroom. Falk Pingel's essay is based on his observation that the web of political, organizational, financial, educational, and academic objectives surrounding international textbook revision has neither been sufficiently investigated from a theoretical point of view, nor described in its specific development with concrete examples. Beginning with considerations pertaining to communications theory, Pingel explores the interaction of different communicative spaces (academic, political, and educational), looking specifically at the bilateral textbook commission between Germany and Poland and international textbook mediation. He demonstrates that these spaces and the discursive strategies associated with them, such as communication discourse versus a discourse of legitimation, both overlap and conflict with each other. Pingel argues that textbook revision projects need to be accompanied by ongoing evaluation and advocates the use of a communications theory approach. However, he acknowledges that this may be very difficult, particularly in conflict situations.

School textbook revision is no abstract concept. It is linked to actors who can be located at different levels: individuals including scholars, educationalists, pacifists, teachers, trade unionists, and politicians; national academic institutions such as the Georg Eckert Institute; NGOs of all kinds and with varying objectives; trade unions; teachers' and other professional associations; international NGOs; and, finally, international government organizations such as UNESCO and the Council of Europe. All of these players form a network in the field of textbook revision that has been little explored to date, but whose functioning is essential for an understanding of the processes of school textbook revision. ${ }^{26}$ It is no coincidence that the guest editors of the present volume are affiliated with two organizations which have been very active in textbook issues - the academic Georg Eckert Institute and the Japanese NGO Peace Boat (Tokyo). ${ }^{27}$ Peace Boat has been one of the key promoters of textbook revision in Japan and East Asia for a number of decades. Since its foundation in 1983, this NGO has particularly striven to improve relations in East Asia (especially Japan's relations with Korea and China) at the grassroots level. It emphasizes the need for crimes of the past to be recognized, acknowledged and understood, so that people today can start to build reconciliation at a people-to-people level, based on mutual respect. This work has taken the form of exchange programs, such as taking young Japanese people to visit historic sites such as Nanjing and the Korean DMZ, and meeting victims and survivors of war, including former sex slaves to the Japanese 
Imperial Army and Korean victims of the atomic bombs on Hiroshima and Nagasaki. It has equally included work on historical reconciliation by lobbying and the development of multilateral history textbooks and pamphlets. Peace Boat has played a central role in the Trilateral History Forum which was established in 2001 to discuss controversial historical events. Besides contributing to a region-wide initiative to write a common history textbook for the region with the objective of building mutual understanding, Peace Boat's own Asian History Project Team is compiling booklets aimed at Japanese youth which tackle the suffering caused by the Japanese military occupations and highlight the viewpoints of other Northeast Asian peoples. ${ }^{28}$

International school textbook revision has lost nothing of its importance. Indeed, in many regions of the world it is still regarded as an effective means of helping to alleviate conflicts over the interpretation of the past, or to present them in such a way as to allow of multiple interpretations. The increase in number and diversity of the parties involved and the emergence of a "historical cyberculture" 29 will lead to a change in the way in which the debates surrounding memory and identity are conducted. Ultimately, however, both now and in the future, textbook revision will hinge on the question of how collective memory, on which national and international consensus may be reached, can be constructed.

Translation, Joy Titheridge

\section{Notes}

1. Antonis Liakos, "History Wars - Notes from the Field," Jahrbuch der Internationalen Gesellschaft für Geschichtsdidaktik 2008/2009: 57-74.

2. Gary Nash, Charlotte Crabtree, and Ross E. Dunn, History on Trial: Cultural Wars and the Teaching of the Past (New York: A. A. Knopf, 1997), 5. See also Thomas Bender, "Can National History Be De-Provincialized? U.S. History Textbook Controversies in the 1940s and 1990s," Journal for Educational Media, Memory and Society 1, no. 1 (2009): 25-38.

3. Maria Repoussi, "Common Trends in Contemporary Debates on Historical Education," Jahrbuch der Internationalen Gesellschaft für Geschichtsdidaktik 2008/2009: 75-90; Susanne Popp, "National Textbook Controversies in a Globalizing World," Jahrbuch der Internationalen Gesellschaft für Geschichtsdidaktik 2008/2009: 109-122. For specific countries, see for Greece, Maria Repoussi, "Politics Questions History Education: Debates on Greek History Textbooks," Jahrbuch der Internationalen Gesellschaft für Geschichtsdidaktik 2006/2007: 99110; for Australia, Stuart McIntyre and Anna Clark, The History Wars (Carlton: Melbourne University Press, 2003); for the U.S.A., Edward Linenthal and Thom Engelhardt (eds.), History Wars: The Enola Gay and Other Battles for the American Past (New York: Metropolitan Books, 1996); for Japan, Sven Saaler, Politics, Memory, and Public Opinion: The History Textbook Controversy and Japanese 
Society (Munich: Iudicum, 2005); Steffi Richter (ed.), Contested Views of a Common Past: Revisions of History in Contemporary East Asia (Frankfurt am Main: Campus, 2008).

4. Eckhardt Fuchs, "Geschichtsunterricht jenseits von Nationalgeschichte: Probleme der Curriculum- und Schulbuchrevision," Informationen für den Geschichts- und Gemeinschaftskundelehrer no. 69 (2005): 17-26.

5. Luigi Cajani, "Historians between Memory Wars and Criminal Laws: The Case of the European Union," Jahrbuch der Internationalen Gesellschaft für Geschichtsdidaktik 2008/2009: 39-55.

6. Cf. Chris Bickerton, "France's History Wars," Le Monde Diplomatique, February 2006, http://mondediplo.com/2006/02/14postcolonial (last accessed $3 \mathrm{Au}$ gust 2010).

7. Eckhardt Fuchs and Simone Lässig, "Europa im Schulbuch," Geschichte für heute. Zeitschrift für historisch-politische Bildung 1, no. 2 (2009): 60-66.

8. Eckhardt Fuchs, Die internationale Organisation der edukativen Bewegung. Studien zu Transfer- und Austauschbeziehungen im Aufbruch der Moderne (forthcoming, Leipzig: Leipziger Universitätsverlag 2011).

9. Carl August Schröder, Die Schulbuchverbesserung durch internationale geistige Zusammenarbeit. Geschichte - Arbeitsformen - Rechtsprobleme (Braunschweig: Westermann, 1961): $42 \mathrm{ff}$.

10. Jan Kolasa, International Intellectual Cooperation (The League Experience and the Beginnings of UNESCO) (Wroclaw: Zakład Narodowy im. Ossolińskich, 1962): 68-69.

11. La Révision des Manuels Scolaires contenant des passages nuisibles à la compréhension mutuelle (Paris: International Institute of Intellectual Cooperation, 1932).

12. Conférence Internationale pour l'Enseignement de l'Histoire - Réunion préparatoire des ler et 2 février 1932 (Paris: Presse Univ. de France, 1932).

13. The German text of the declaration is printed in Schröder, Die Schulbuchverbesserung, 1961, 193-194.

14. On the role of school textbooks in shaping France and Germany's image of each other following 1918, see Rainer Bendick, "Die Schulbücher der Feinde. Wahrnehmung und Wirkung in Deutschland und Frankreich vor und nach 1918," Internationale Schulbuchforschung 22, no. 3 (2000): 301-314.

15. Schröder, Die Schulbuchverbesserung, 1961, 194-195.

16. Falk Pingel, UNESCO Guidebook on Textbook Research and Textbook Revision (2nd revised and updated edition) (Paris: Unesco; Braunschweig: Georg-EckertInstitut, 2010); Fuchs, Internationale Schulbuch- und Curriculumrevision.

17. Gregory Wegner, “Germany's Past Contested: The Soviet-American Conflict in Berlin over History Curriculum Reform, 1945-48," History of Education Quarterly 30 (1995): 1-16.

18. Yoko Thakur, "History Textbook Reform in Allied Occupied Japan, 1945-52," History of Education Quarterly 35 (1995): 261-278.

19. Otto-Ernst Schüddekopf, Zwanzig Jahre Westeuropäischer Schulgeschichtsbuchrevision 1945-1965. Tatsachen und Probleme (Braunschweig: Limbach, 1966): 18-19, $25 \mathrm{ff} ., 56 \mathrm{ff}$.

20. Vol 1: Histoire/Geschichte - Europa und die Welt seit 1945 (Leipzig: Ernst Klett, 2006); Vol. 2: Histoire/Geschichte - Europa und die Welt vom Wiener Kongress bis 1945 (Leipzig: Ernst Klett, 2008). 
21. A list of the international conferences about the revision of school history books held between 1945 and 1965 can be found in Schüddekopf, Zwanzig Jahre, 1966, $89 \mathrm{ff}$.

22. Against Bias and Prejudice: The Council of Europe's Work on History Teaching and History Textbooks. Recommendations on History Teaching and History Textbooks Adopted at Council of Europe Conferences and Symposia 1953-1983 (Strasbourg: Council for Cultural Co-operation, 1986); Maitland Stobart, "Fifty Years of European Co-operation on History Textbooks: The Role and Contribution of the Council of Europe," Internationale Schulbuchforschung 21 (1999): 147-161.

23. Against Bias, 1986, 7 and 36.

24. Falk Pingel (ed.), Macht Europa Schule? Die Darstellung Europas in Schulbüchern der Europäischen Gemeinschaft (Frankfurt am Main: Diesterweg, 1995).

25. Frédéric Delouche, Europäisches Geschichtsbuch (Stuttgart: Ernst Klett, 1992); Stobart, 1999, 151.

26. Research into the networks on the level of the actors involved in international textbook revision is the aim of the project "History Beyond Borders: The International History Textbook Revision, 1919-2009," which is supported by the Swedish Research Council and led by Daniel Lindmark and Eckhardt Fuchs (German sub-project).

27. A conference on "Textbook Revision and Peace Education Revisited: Past Experiences - Present Expectations - Future Concepts" that was organized by Eckhardt Fuchs and Yoshioka Tatsuya in Beijing in 2008 was also supported by the international NGO Asia-Europe Foundation (Singapore), which was established in February 1997 by the participating governments of the AsiaEurope Meeting (ASEM) and promotes mutual understanding between the two regions through intellectual and cultural exchanges.

28. On Japan (in addition to the literature mentioned in note 3), see Shinichi Arai's historical overview in the forum section of this volume, and Yoshiko Nozaki and Mark Selden, "Historical Memory, International Conflict, and Japanese Textbook Controversies in Three Epochs," Journal for Educational Media, Memory and Society 1, no. 1 (2009): 117-144.

29. Liakos, "History Wars," 2008/09, 68. 